\title{
SECONDARY SOCIALIZATION OF CHILDREN FROM HOME EDUCATION
}

\author{
Michal Hanák ${ }^{1}$, Václav Šimek ${ }^{2}$, Kateřina Bočková ${ }^{3}$
}

\begin{abstract}
The aim of this paper is to find out how the secondary socialization of children from home education takes place and to map the personal experiences and opinions of parents educating their children at home. The paper is divided into theoretical and empirical parts. The theoretical part deals with the socialization as a necessary process in the life of each individual, we describe the various types of socialization, we deal with a different concept of socialization according to where it takes place, i.e. in the home and school environment. The theoretical part forms the basis for the empirical part. For the implementation of the research, we chose qualitative research using semi-structured interviews, which were conducted with parents who currently have a child or children in home education. According to the results of the research, home schooled children are secondarily socialized in regular and sporadic meetings with other home schooled children, either as part of celebrations and other social events or for the purpose of learning together in a small group of children. Another way are friends with whom they see each other several times a week in hobby groups or visit each other. Furthermore, the family and siblings, play an important role in the socialization process. Due to age differences, siblings can help each other in many ways, learn from each other and spend free time together. The limit of the presented work is a small sample of respondents and the associated impossibility to generalize the results. However, the research went into depth on the topic and brings forward the subjective opinions and experiences of parents. Another limit is the implementation of the interviews through the telephone, which does not allow for the observation of non-verbal expressions of the respondents during the interview, which can reveal a lot.
\end{abstract}

UDC Classification: 37.06, DOI: https://doi.org/10.12955/pss.v2.212

Keywords: home education, socialization, child, family, parents, school, teacher.

\section{Introduction}

Home education is viewed in two opposing ways. There are many supporters but also opponents of this different way of education. Some are on the side of the school, which according to them represents a natural environment for the appropriate cognitive and social development of the child, others consider the home as this environment. The question remains whether it is clear which of them is right. However, the phenomenon of home education is not so widespread in Czech Republic in relation to the number of pupils normally educated in schools, but according to the Statistical Yearbook (MŠMT, 2019) it can be stated that the number of children educated in this way is increasing in the hundreds from year to year. Although home education has been legal in other countries for several decades, in the Czech Republic it is not so long ago that it was only made legally allowed at both levels of primary schools. Therefore, this topic can be considered relatively current, given the date of its legalization in our country. The home education was legalized in 2016 in Czech Republic and in 2021 in Slovakia.

Socialization is considered to be the most debated topic in home education, and insufficient socialization is the most frequently cited reason for opponents of this alternative style of education. Two completely different views on socialization come into conflict. Some claim, for example Štech (2003), that homeeducated children live in isolation and grow up in so-called greenhouse conditions. Others, such as Mertin (2003), assume, that the home environment is more suitable for socialization than a school in which there are many negative influences that parents want to protect their children from. Several studies on the socialization of children from home education, such as Kunzman \& Gaither (2013), Medlin (2013), and Ray (2017a; 2017b), point to the fact that home-educated children are developing just as well socially, if not better than public school children. For example, an analysis of home education performance in the United States confirms that home-educated children are mature, have good leadership skills, interact well with both peers and adults, have no social anxiety, or have problematic behavior. Overall, they manifest themselves with prosocial behavior and social responsibility, as reported by Murphy (2014, pp. 37-38). "School and family are inextricably linked to each other, and how a child thrives at school is not only his personal identity, but also an indicator of family functionality," says Štech (2003, p. 424). And although these two institutions differ in many ways, they have one thing in common: to ensure the child's maximum development.

Research on socialization, socialization skills and the social interaction of home-educated children is completely absent in the Czech environment. The only available sources are foreign research. A possible

\footnotetext{
${ }^{1}$ DTI University Dubnica nad Váhom, Slovakia, studijni@i-academy.eu.

${ }^{2}$ DTI University Dubnica nad Váhom, Slovakia, VSimek@seznam.cz.

${ }^{3}$ DTI University Dubnica nad Váhom, Slovakia,. bockova@dti.sk, ORCID: 0000-0002-3728-628X
} 
reason for the lack of research may be that home education in primary schools was legalized in the Czech Republic only in 2005 and 2016. For this reason, it is important to pay more attention to this topic.

Because home education does not have such a long tradition in our country and is not as widespread as in other countries, it can be unrecognized and stigmatized by society, for several reasons. For example, due to irresponsible parenting, academic arrogance, excessive social protection, moral extremism, and the exaggerated bond between mother and child, as confirmed by Lois (2018, pp. 69-88). According to Kašparová (2019, pp. 129 - 130), home education is stigmatizing by society mainly for reasons related to socialization, concepts such as "social isolation, exclusion or child in a greenhouse" are most often mentioned, along with the irreplaceable role of the peer collective is mentioned as well. The answer to whether this is true or not is provided by the present paper.

\section{Literature Review}

\section{Socialization in the Home Environment}

The family is the primary group for a child, in which his or her personality is formed from birth to adult life, and at the same time represents a safe, emotional and supportive environment, to which Havlík \& Kot'a (2002, p. 67) and Vágnerová (2012, p. 313) agree. During the socialization process, the child is affected by patterns (parents, older siblings), either positively or negatively. Parents can also be "models for the future" for their descendants, which consists in a child's idea of their own future, which is identical with the life of the parents, adds Vágnerová (2012, p. 315). Kraus \& Poláčková (2001, pp. 8081) state that the family lays the foundation for the child's ability to establish social relationships and prepares him for practical life. It is also responsible for the upbringing of children and plays a key and irreplaceable role in this regard. Maňák et al. (1998, pp. 57-59) adds that family education is important in creating a child's relationship with society in the sense that the child is informally influenced by the views of his parents.

The social environment and society can be perceived by individuals as an advantage and a part of life, or, conversely, as a certain limitation. The way of this perception is predetermined already in the microenvironment by the style of education already taking place in early childhood, states Řezáč (1998, p. 46). There is a positive socialization in the family, which is connected with the child's self-esteem and its feeling of being needed and wanted. This then leads to the child being independent and a peer group in society. The child should remain in the family environment and should not be included in a larger team until it is able to think independently, says Kostelecká (2014, p. 75). According to Rabušičová (1991, p. 33), it is "even better to wait until the child himself begins to require contact with other children, but it ultimately depends on the social maturity of the child".

According to Mertin (2003, p. 415), the undeniable advantage of home education is that the family spends more time together, which leads to a favorable development of the child. Common experiences form family history and participate in mutual coexistence, claims Vágnerová (2012, pp. 33-325). Vágnerová (2012, pp. 315-325) further adds that the relationship between siblings, which brings a certain social experience, is also significant. Siblings compete with each other, learn to work together and influence each other. To some extent, sibling coexistence also depends on whether their parents treat all children in the same way. It can be assumed that in families with more children, socialization within the family can be ensured. However, what may seem problematic are families with only one child. According to a nationwide study of academic success and demographics of home-educated children, conducted by Ray (2010) on 11,739 children from home education, only $6.6 \%$ of families had only one child. On average, there are 3.5 children under the age of 21 in families with home education. The average number of children in families in the United States under the age of 18 in 2010, when the above-mentioned research was conducted, was 1.88 children (Statista, 2020).

Although the family is considered as a place for primary socialization, in the case of home education it is necessary that secondary socialization is also ensured in some way. Therefore, it is important that the family does not live in isolation but that it is in regular contact with support groups or communities of schoolchildren. These communities tend to be very helpful not only for starting families with home education. According to Jančaříková (2016, p. 229), there is mutual support, organization of joint events, transfer of experience with pedagogical methods, suitable textbooks and various teaching aids that can make learning at home more effective. Urbánková (2018) adds that the support groups are not only for 
mothers (parents) who exchange their experiences, advice and tips, but also for mothers (parents) with children. A program is prepared for children, during which a team is created, in which socialization then takes place, children cooperate and learn social skills. Kašparová \& Láníková (2016, p. 55) further states that even in hobby groups, sports clubs or other social facilities, children from home education have the opportunity to come into contact with both a very wide range of peers and an age-heterogeneous team.

Another possibility to be in contact with other home-based families are social networks, through which it is possible to connect with families conducting home education from all over the country, adds Kašparová (2019, pp. 54-56). Parents can share their successes and failures, counsel and support each other. They can then find more professional help on portals dealing with home education or directly in schools that offer online counseling with a school psychologist.

\section{Socialization in the School Environment}

Kraus \& Poláčková $(2001$, p. 86) argues that the school, as a typical socialization institution, has as one of its tasks and functions to prepare pupils for the next life, in terms of acquiring social skills, responsibility for their behavior, the ability to orient oneself, and avoiding social pathological phenomena. Vágnerová $(2012$, p.312) adds that the individual has the opportunity to develop its characteristics and skills, which may be important for its future career. Maňák et al. (1998, p.57) admits that although the family is primarily responsible for the upbringing of a child, at a certain age part of the upbringing is left to school or other educational institutions due to the complex development of the child. Štech (2007) is convinced that school socialization contributes to children's independence and responsibility not only to themselves but also to society as a whole, as well as to the autonomy of the individual, as pupils at school must abide by generally applicable rules. "Discipline, unlike family, is ensured at school by impersonal rules and disciplinary measures. Ideally, it should be based on the pupil's motivation for knowledge, which the school systematically teaches the child to develop for further (deeper) knowledge" (Štech, 2003, p. 423).

By entering school, an individual acquires new social roles (schoolboy, pupil, classmate) and thus the obligation to meet certain requirements and to respect new norms and values (Vágnerová, 2012, p. 331). Contact with peers is seen by proponents of school attendance as one of the positive aspects of school education. School attendance is a specific cultural creation of today's Western society, enabling the acquisition and shaping of ways of thinking, behaving and feeling, without expending much energy and unnecessary losses. Cognitive socialization and the formation of mental structures of an individual are also connected with school. "At school, children come into contact with peers and with adults other than their parents" (Štech, 2003, p. 426). Even in early childhood, the relationship with parents determines the patterns of behavior with teachers and peers, problematic family relationships can lead to antisocial behavior (Mertin, 2003, p. 414). The school environment is formed randomly, where pupils from families with different socio-economic status meet. Thanks to this, pupils learn to develop given peer relationships, they learn cooperation, competitiveness and prosocial behavior (Štech, 2003, p. 427). From the ninth year of life, peer relationships become more stable. Common interests, individual needs and gaining a place in society play an important role. Maňák et al. (1998) believe that contact with peers is essential for proper social development. Early peer relationships are a prerequisite for establishing future relationships and friendships. Vágnerová (2012, p. 339) is convinced that thanks to the peer group, the individual ceases to be so much fixed on the family and gains a completely different experience than in the family.

According to Řezáč (1998, p. 206), the school class as a formal social group is very important for the life of an individual, for example in the completion of personality traits. Same-sex groups are usually formed in the classroom. The position of an individual in this group is determined by learning activities, teachers also evaluate the pupil's personality according to this characteristic. According to Vágnerová (2012, pp. 347-348) at a later age, other factors also contribute to the child's position in the class hierarchy, such as social competence, self-confidence or a certain skill that is admired by others. Rabušicová (1991, p. 33) adds that it is common for those who play the role of entertainer in the classroom to be valued, while those who are smart and obedient are despised by others. According to Helus (1991), pupils move toward average results for classmates to adapt to the class pressure that is directed at the individual who would like to deviate from the average. Thus, in school there is not only positive peer socialization (cooperative learning, communication, peer assistance), but also negative socialization, such as bullying (Mertin, 2003, p. 408). 


\section{Data and Methodology}

The aim of this paper is to find out how the secondary socialization of children from home education takes place, and to specify and approach the given methods more from the point of view of educating parents. The results of our research can be a stimulus for professional discussion. At the same time, they can be beneficial not only for students of pedagogical disciplines, but also for teachers, home educators or creators of educational strategies. Overall, the topic of home education in Czech Republic is not empirically mapped, and therefore this research may be a suitable contribution to supplement this missing area.

According to Nakonečný $(2005$, p. 30), the secondary socialization takes place mainly at school and in a group of peers. We were interested in how children who do not go to school and thus do not spend most of the day in a group of peers are secondary socialized, but at home with their parents or siblings.

Based on the formulated research aim, we set a basic research question: How is the secondary socialization of children from home education?

We divided the basic research question into 5 specific research questions (SRQ), which we present bellow:

SRQ1: From the point of view of parents from home education, how is the contact of their children with other children ensured?

SRQ2: What importance do parents from home education attach to the home education community?

SRQ3: From the point of view of parents from home education, what role does the family play in the socialization of their children?

SRQ4: From the point of view of parents from home education, what is the significance of school in the socialization of children?

SRQ5: How do parents from home education assess their child's social skills?

\section{Qualitative Research}

We chose qualitative research because qualitative research does not depend on theory or established hypotheses. It is an in-depth investigation of the phenomenon and obtaining a large amount of information. During the research, the researcher tries to penetrate into the given situation, because only in this way he can understand the given phenomenon as much as possible and understand the examined person as well as possible, explains Gavora (2000, p. 31). Thanks to the fact that the study of people in a qualitative research takes place in their "authentic environment", the researcher can understand the researched phenomenon as it naturally takes place, adds Švaříček \& Šed'ová (2014, p. 17). In the case of our research, the natural environment was the homes of the families where some of the interviews took place.

Because the qualitative methodology is based on induction, the researcher first collects the data and looks for regularity in the data. Based on the collected data, he sets preliminary conclusions and only then begins to formulate new hypotheses and theories, says Disman (2002, p. 287).

The results of the qualitative research are non-numerical and apply only to the sample examined, and therefore cannot be generalized to the entire population. Unlike quantitative construction, qualitative research is aimed at creating new hypotheses and theories, deep immersion in given cases and discovering hitherto undiscovered connections, add Disman (2002, p. 286) or Gavora (2000, p. 31).

\section{Data Collection Technique and Ethical Dimension of Research}

We chose an in-depth semi-structured interview as the data collection technique. Using this technique, we found out how children from home education are secondarily socialized from the point of view of their educational parents. Before the actual interviews with the respondents, we prepared a scheme of a semi-structured interview. We started from a basic research question.

Data were collected using a sound recording on a dictaphone in a mobile phone. Only two of the interviews were conducted at the respondents' home, the others were conducted by telephone, due to the situation caused by the COVID-19 pandemic. Telephone interviews have the advantage over face-toface interviews in that they provide greater anonymity, which may be more pleasant for some respondents, as mentioned by Disman (2002, p. 145). However, they also have their limits, which we 
found in the fact that we did not see the respondents, and therefore could not record their non-verbal signals.

For the analysis and interpretation of the data, literal transcripts of all conducted interviews were used.

During the research, all ethical aspects mentioned by Švaříček \& Šed'ová (2014, pp. 45-49) were observed. Credibility was ensured by anonymity, when no further information about the families was communicated and pseudonyms for each of the families were used in the data processing itself. Before the actual recording, we acquainted the respondents with the aim of the research, then we asked them for their consent to participate in the research and permission to record our interview. The request for consent to participate and record the interview was then repeated once more on the recording device. At the end of the interview, all respondents were offered the mediation of research results in electronic form.

\section{Validity and Reliability of Research}

Each research technique has two basic properties, namely validity and reliability. Qualitative research is characterized by low reliability and higher validity. Low reliability is due to the fact that the same or similar results cannot be achieved when research is replicated, as qualitative research examines specific phenomena that are constantly changing. Therefore, the results cannot be generalized. Likewise, the results of our research are not valid for all families with home education, but only for those who were part of our research.

On the contrary, the validity is higher in qualitative research. In the interview we used in our research, validity is ensured by the fact that there is the interpersonal contact with the respondent, during which the researcher obtains a unique statement from the examined persons. The more spontaneously, openly and honestly the respondent answers the researcher's questions, the higher the validity of the answers, says Diman (2002, p. 145) or Gavora (2000, p. 146).

\section{Selection of Research Sample}

Deliberate selection is typically used for qualitative research. In carrying out our research, we focused on families in which home education is currently taking place, at the first or second level of primary school. Specifically, we used cumulative selection in the implementation of intentional selection. This procedure, called "snowball sampling", consists in the fact that the circle of people with whom the researcher works in his research is gradually expanding, defined by Gavor (2000, p. 144).

Data collection took place from September 2020 to December 2020. We gained contacts with families due to the fact that one of the authors of the paper has a child in home education who is a pupil of the Elementary School Březová, which significantly supports home education and provides full online support. The school became a mediator for mediating contacts with respondents.

We arranged a personal meeting or the time for a telephone conversation with the families by phone or email. The personal conversation took place with only two mothers, the others were conducted via telephone or Internet applications. The average length of interviews was about 40 to 60 minutes.

\section{Characteristics of the Research Sample}

The research sample consisted of 57 Czech and 3 Slovak families. The respondents were mothereducators and one father. The main criterion for the selection of samples was that families have at least one child currently in home education, either in the first or second level of primary school. The numbers of children in families were higher, mostly three to four children, in one family there were only two, in one family only one. It was a total of 202 home-educated pupils.

\section{Results and Discussion}

The first specific question was this: From the point of view of parents from home education, how is the contact of their children with other children ensured? All respondents stated that their children have contact with friends or foreign children at least once a week, in most families almost every day. Contact is secured in several ways. Children visit their friends at home or meet them outside. These are often friends from family, neighborhood or former classmates. Another possibility of contact is interest groups, which, except for one, all children from the responded families visit, many of them several times a week. Last but not least, there are excursions and other events with the current school or the community of schoolchildren. Most families do not use the current school offers very often. The reason is the distance of the school, the unsatisfactory time or the feeling of disruption of the class structure by a 
foreign element, which is a home-educated pupil. Other families, on the other hand, praise the cooperation with the current school and use the offers of school events.

The school is also associated with the topic of peer needs, which, if necessary, can be met in this way. However, all parents agreed that they do not perceive the deficit of the peer group in any of the children, and on the contrary emphasize the contact with the age-heterogeneous group, which is more natural for individuals, also in terms of adult life. In addition to physical contact, home-educated children can also connect with friends via social networks, but most children are not allowed by their parents due to their young age, so physical contact predominates in all of them.

The second research question was: What importance do parents from home education attach to the home education community? Many home education based families associate in communities or home education support groups. Here, too, it is possible to use the power of social networks and make friends, exchange views, experiences and advice with other home education based families. These communities bring many benefits not only to children, but also to the parent-educators themselves. It is beneficial for children that in such community gatherings they have the opportunity to socialize and make friends with children who are educated in the same way as them. The experiences of these meetings are also important, it is often a celebration of various holidays, but also walks and games in nature. Communities also visit theaters, museums and galleries. Parents can share with each other their personal knowledge and findings from the area, but also the doubts and disappointments experienced by many home educators. It can also be an advantage that mothers can take care of each other's children, which gives them some free time, which educational mothers are modest about, because they play two important roles on a daily basis. Some of the families in the communities are not involved, because, for example, they do not have other families with home education in their vicinity or they prefer sporadic meetings. Communities can also be used for co-learning, bringing together a small group of children of different ages and one mother learning with the children.

The third research question asked: From the point of view of parents from home education, what role does the family play in the socialization of their children? The family has an irreplaceable place in home education. Siblings are important, who spend time together, cooperate and learn from each other. Older siblings are role models for younger ones and help them. Even parents are a role model and support for their children. Thanks to home education, which allows parents with children to spend time intensively, they have the opportunity to really get to know their children, follow them and fulfill their needs and interests. There is enough space for deepening trust, which then leads to improved family relationships in all directions.

The fourth research question asked: From the point of view of parents from home education, what is the significance of school in the socialization of children? Socialization has been and still is influenced by school. Some children from the surveyed families have attended school in the past or still attend it a few days a week. According to the respondents, the school with a non-individual approach and a restrictive daily routine is the most limiting. The absence of support and emotional relationships was also mentioned. School, on the other hand, brings completely new interactions and experiences that the home cannot provide.

The fifth and final question was this: How do parents from home education assess their child's social skills? The children of the respondents do not live in isolation and, according to their parents, show prosocial behavior. They are able to make contact and communicate with both children of their age and adults, because they spend their free time mostly in an age-heterogeneous group. Cooperation begins in the family thanks to the higher number of children in families and is reflected in visits to hobby groups or community meetings.

After summarizing the answers to all specific questions, it is possible to answer the main research question: How is the secondary socialization of children from home education? According to the results of the research, home-educated pupils are secondarily socialized in regular and sporadic meetings with the community of home-educated children, either as part of celebrations and other social events or for the purpose of learning together in a small group of children. Another way they socialize are friends with whom they see each other several times a week in hobby groups or visit each other. Furthermore, the family and siblings play an important role in the socialization process. Due to age differences, siblings can help each other in many ways, learn from each other and spend free time together. 
A comparison of the results, which state the reasons for choosing home education, which are indirectly based on our interviews, with the results of foreign research conducted by Ray (2017a) shows that we find two groups of reasons for choosing home education - practical and ideological, as divided by Kašparová (2019, pp. 26-31). The most common practical reasons were certain health, physical or psychological disadvantages, in our research it was dyslexia and antisociality. Among the ideological reasons, dissatisfaction with the school system, the transmission of one's own philosophy of life, religious education or protection against socially pathological phenomena are the most mentioned. In our research, among ideological reasons, the negative experience with school was most often mentioned.

Murphy's (2014) research on socialization confirmed leadership skills, prosocial behavior, social responsibility, and the ability to interact in home-educated pupils. Likewise, the statements of the respondents in our research confirm that home-educated pupils can establish contact, cooperate in a group, communicate with both children and adults and act mature and responsibly. Our results are also in correlation with the results of Kunzman and Gaither (2013) or Ray (2017b), who argue that homeeducated pupils are less peer-oriented than school children. This is confirmed by the statements of parents who prefer contact with an age-heterogeneous group for their children, which brings more benefits than an age-homogeneous group. Their interactions have a wider reach and involve both children and adults, making it possible to acquire adequate social skills. Community involvement and various activities with parents also bring many opportunities for socialization. In his research, Ray (2017b) mentions "team sports, cooperative learning, church activities and community service." As part of our findings, we mention activities with the community, the current school, group learning together, hobby groups and the family. Our work is in correlation with the results of Atkinson et al. (2007 in Medlin, 2013), which emphasize the importance of providing various resources and opportunities for socialization such as: "family and friends, local home education communities, church organizations, sports programs and the Internet." Likewise, in our research, one of the possibilities was to contact friends via the internet or activities within the rectory. Medlin (2013) mentions in his research that children from home education are "actors of their own socialization", which is in line with our finding that children have different needs in terms of contact with friends, so they determine how often and intensive their socialization will be. We would add that it also depends on the parental stimuli that they want and can provide to their descendants.

The limit of our research is a small sample of respondents and the associated impossibility to generalize the results. However, the research went into depth on the topic and brings forward the subjective opinions and experiences of parents. Another limit, as mentioned above, are the telephone conversations, which do not allow for the observation of non-verbal expressions of the respondents during the interview, which can reveal a lot.

\section{Conclusion}

Socialization in both the home and school environment has its limits, but also its advantages. However, they are united by the same goal, and that is above all the healthy moral and social development of the individual. The advantages of socialization in the home environment can be considered that the home environment is safe and without negative influences that could adversely affect the child. Furthermore, it is time spent together that contributes to the development of family relationships. Last but not least, the fact that the child is approached individually at home, with respect for his current interests and needs, and so it is possible to develop his individuality. Conversely, disadvantages may be when the family is not involved in any support group or community and lives separately. It can also be limiting when there is only one child in the family who does not have the opportunity to cooperate with the siblings, to interact, to help each other and to develop socially.

The advantages associated with socialization at school are, for example, establishing new relationships, the possibility of comparing with classmates, competition and cooperation. The dark side of school socialization is the various socio-pathological phenomena that occur at school, from bullying to alcohol and drugs. Furthermore, disrespect for individuality.

The role of the teacher as a parent and the teacher as a stranger also has its strengths and weaknesses. As a teacher, a parent knows his child best and wants to provide the best for him. Possible difficulties may arise with insufficient professional knowledge of parents who do not have pedagogical education. Furthermore, it is the approach to the child in education or evaluation of educational results, which may 
not always be objective due to the close relationships. On the other hand, if the teacher is a stranger, his approach is very objective, he can ensure discipline and compliance with the set rules. Above all, however, the teacher is an expert with a pedagogical education.

As has been mentioned several times, the range of research in Czech Republic is very limited, so it is important to pay more attention to this topic from any angle and to raise awareness among the general public about this style of education, which has the potential to be, we do not think for all but for some children, in many ways helpful and beneficial.

\section{Acknowledgements}

The presented paper was processed as an output of the project IGA 004/2020 Secondary socialization of children in home education financed by the DTI University, Dubnica nad Váhom, Slovakia.

\section{References}

Disman, M. (2002). Jak se vyrábí sociologická znalost: př́ručka pro uživatele. [How sociological knowledge is produced: a user guide]. Praha: Karolinum.

Gavora, P. (2000). Úvod do pedagogického výzkumu. [Introduction to pedagogical research]. Brno: Paido.

Havlík, R., \& Kot’a, J. (2002). Sociologie výchovy a školy. [Sociology of education and school]. Praha: Portál.

Helus, Z. (1991). K socializaci výchovy, vzdělání a školy. [To socialize upbringing, education and school]. Brno: Masaryk University, Faculty of Art.

Jančaříková, K. (2016). Domácí vzdělávání - př́ležitost pro děti se specifickými vzdělávacími potřebami: případová studie žáka s dyslexií. [Home education - an opportunity for children with special educational needs: a case study of a pupil with dyslexia]. Stati didaktické a metodické, 224-260.

Kašparová, I. (2019). Spolu: Průvodce domáciho vzdělávání v České republice. [Together: Guide to Home Education in the Czech Republic]. Brno: Akademia.

Kašparová, I., \& Láníková, M. (2016). Centraizovat, nebo rozvolnit? Analýza diskuse o indivuduálním vzdělávání na půdě poslanecké sněmovny ČR optikou teorie modernity Perera Wagnera. [Centralize or loosen? Analysis of the discussion on individual education in the Chamber of Deputies of the Czech Republic from the perspective of Perer Wagner's theory of modernity]. Studia pedagogika, 21(3), 41-61. https://doi.org/10.5817/SP2016-3-3

Kostelecká, Y. (2014). Doma, nebo ve škole? [At home or at school?]. Studia pedagogika, 19(1), 65-82. https://doi.org/10.5817/SP2014-1-4

Kraus, B., \& Poláčková, V. (2001). Člověk-prostředí-výchova: K otázkám sociální pedagogiky. [Man-environmenteducation: On issues of social pedagogy. JBrno: Paido.

Kunzman, R., \& Gaither, M. (2013). Homeschooling: A Comprehensive Survey of the Research . Other Education: The Journal of Educational Alternatives.

Lois, J. (2012). Home is where school is: The logic of homeschooling and the emotional labour of mothering. New York and London: New York university press. https://doi.org/10.18574/nyu/9780814752517.001.0001

Maňák, J., Prokop, J., \& Solfronk, J. (1998). Kapitoly ze sociální pedagogiky a psychologie : př́spěvek ke vzdělávání učitelů. [Chapters from social pedagogy and psychology: a contribution to teacher education]. Brno: Paido.

Medlin, R. G. (2013). Homeschooling and the Question of Socialization Revisited. Peabody Journal of Education, 75(1-2). https://doi.org/10.1080/0161956X.2013.796825

Mertin, V. (2003). Pedagogicko-psychologické aspekty individuálního vzdělávání. [Pedagogical-psychological aspects of individual education].Pedagogika, 53, 404-417.

MŠMT. (2019). MŠMT, Odbor školské statistiky, analýz a informační strategie. [Ministry of Education, Department of School Statistics, Analysis and Information Strategy]. Retrived from http://toiler.uiv.cz/rocenka/rocenka.asp

Murphy, J. (2014). The Social and Educational Outcomes of Homeschooling. https://doi.org/10.1080/02732173.2014.895640

Nakonečný, M. (2005). Sociálni psychologie organizace. [Social psychology of organization]. Praha: Grada.

Rabušicová, M. (1991). K sociologii výchovy, vzdělání a školy. [On the sociology of education and school]. Brno: Masaryk University, Faculty of Art.

Rabušicová, M., \& Emmerová, K. (2003). Role rodičů ve vztahu ke škole - Teoretické koncepty. [The role of parents in relation to school - Theoretical concepts]. Pedagogika, 141-151.

Ray, B. D. (2010). Academic achievement and demographic trait of homeschool student. https://doi.org/10.1080/15582159.2017.1395638

Ray, B. D. (2017a). A systematic review of the empirical research on selected aspects of homeschooling as a school choice. Journal of School Choice, ,11:4, 604-621. https://doi.org/10.1080/15582159.2017.1395638

Ray, B. D. (2017b). A Review of research on Homeschooling and what might educators learn. National Home Education Research Institute. https://doi.org/10.1590/1980-6248-2016-0009

Řezáč, J. (1998). Sociální psychologie. [Social psychology]. Brno: Paido.

Statista. (2020). Average number of own children under 18 in families with children in the United States from 1960 to 2019. Retrived from https://www.statista.com/statistics/718084/average-number-of-own-children-per-family/ 
Štech, S. (2003). Škola, nebo domácí vzdělávání? Teoretická komplikace jedné praktické otázky. [School or home education? Theoretical complication of one practical question]. Pedagogika, 53, 418-43.

Štech, S. (2007). Mise školy - chránit kulturu i rozvíjet ditě. School mission - to protect the culture and develop the child]. Retrived from https://konzervativizmus.sk/mise-skoly-chranit-kulturu-i-rozvijet-dite/

Švaříček, R., \& Šed'ová, K. (2014). Kvalitativní výzkum v pedagogických vědách. [Qualitative research in pedagogical sciences]. Praha: Porál.

Vágnerová, M. (2012). Vývojová psychologie: dětství a dospívání. [Developmental psychology: childhood and adolescence]. Praha: Karolinum. 